Original Research

\title{
Effect of Slope Gradient on Phosphorus Loss from a Sloping Land of Purple Soil under Simulated Rainfall
}

\author{
Xiaoling He${ }^{1}$, Zicheng Zheng1*, Tingxuan $\mathrm{Li}^{1}$, Shuqin $\mathrm{He}^{2}$ \\ ${ }^{1}$ College of Resources, Sichuan Agricultural University, Chengdu, Sichuan, People's Republic of China \\ ${ }^{2}$ College of Forestry, Sichuan Agricultural University, Chengdu, Sichuan, People's Republic of China
}

Received: 26 March 2019

Accepted: 29 May 2019

\begin{abstract}
Phosphorus ( $\mathrm{P}$ ) and sediment loss through runoff to surface and ground waters represents a risk to human and environmental health. We investigated the characteristics of $\mathrm{P}$ loss of maize seedlings on different slope gradients under a simulated rainfall experiment. Surface runoff and sediment were highest on the $20^{\circ}$-slope and lowest on the $15^{\circ}$-slope. The $20^{\circ}$-slope showed least $\mathrm{P}$ loss in runoff, which accounted for $57 \%$ and $50 \%$ of those on $10^{\circ}$ - and $15^{\circ}$-slopes, respectively. Available phosphorus (AP) losses in sediment on the $20^{\circ}$-slope were 7.6 and 4.2 times as much as that on the $10^{\circ}$ - and $15^{\circ}$-slopes, correspondingly. Subsurface runoff and $\mathrm{P}$ losses increased with slope gradients increasing, whereas P loss in subsurface runoff was lower than that in surface runoff. The runoff-sediment-yield demonstrated an increase during rainfall events, whereas $\mathrm{P}$ concentration in surface runoff rose and then declined before stabilizing. $\mathrm{P}$ form losses increased first and then decreased along with increasing slope gradients. Slope gradients had little influence on AP in sediment. The dissolved total phosphorus (DTP) loss dominated the TP loss in runoff. P losses exhibited a complex relationship with runoff-sediment-yield, and different P-form and each item cannot exist on its own or occur independently. Controlling soil and water losses is necessary to alleviate P losses in slope farmlands.
\end{abstract}

Keywords: slope gradient, phosphorus (P) loss, purple soil, simulated rainfall

\section{Introduction}

Slope farmland covers an area of $3,513 \times 10^{4} \mathrm{~m}^{2}$ in China, which is a major source of soil and water losses. Soil erosion has been identified as one of the major processes contributing to soil and water quality

*e-mail: zichengzheng@126.com degradation [1-4]. Recently, the application of excessive fertilizers and manures to agricultural land can increase the level of phosphorus $(\mathrm{P})$ in the purple soil region of Sichuan, China. P is the element primarily responsible for water eutrophication. The loss of $\mathrm{P}$ with soil erosion can cause environmental problems due to their effect on water eutrophication [5]. P loss in the purple soil of sloped farmlands has caused much concern [6-9]. Thus, studies should consider $\mathrm{P}$ loss caused by runoff and sediments. 
Slope gradient is a major effect factor in soil erosion and $\mathrm{P}$ transport on slope farmland. Many studies have noted the importance of slope condition in soil erosion and P loss [5, 10-11]. Several studies have reported that the runoff coefficient was a function of slope gradient and rainfall intensity in different slope gradient cases [4, $10,12]$. The amount of total erosion tends to stabilize with an increase in slope gradients, which implies there is probably a threshold slope gradient at which soil erosion begins to shift from strong to weak [13]. Fu et al. [14] found that the amount of wash load increased with an increasing slope gradient if the gradient was less than 58\%; alternatively, the opposite relationship was observed at steeper slopes. However, overland flow displayed an increasing runoff coefficient with increasing slope gradient until a critical value was reached, as observed in the range of $17.6^{\circ}$ to $36.4^{\circ}$. Moreover, runoff and $\mathrm{P}$ loss increased with increasing slope gradient [9-10]. Many studies were based on a discussion of critical slope or characteristics of P loss at the surface, but there is still insufficient data for $\mathrm{P}$ loss in subsurface runoff. The lack of experimental studies is due to the difficulty of monitoring variation in subsurface runoff [1, 10-14].

In Sichuan, China, $80 \%$ of the purple soil region is low mountains, hills, and valleys; the slope gradients in these regions range from $7^{\circ}$ to $25^{\circ}$. Approximately $46.2 \%$ of soil loss comes from cultivated slope farmlands in this region [15].

Maize is one of the major cultivars of the purple soil region in Sichuan, China. Purple soils are thin Entisols with high erosivity, and strong dispersibility and is the potential contribution source of colloidal particles [12]. In addition, the coverage is low during the maize seedling stage. Purple soils loss are known to have remarkable capacity to carry and transport P [16]. Raindrops have a strong destructive power and kinetic energy during rainfall events, causing the formation of large amounts of runoff and sediments. Therefore, purple soil erosion and $\mathrm{P}$ loss caused by rainfall, which has become the main source of non-point source pollution in the Three Gorges Reservoir area, have created the increasingly serious social and environmental problems of declining crop yields [9, 17-18].

In this study, we investigated the impact of slope gradient on $\mathrm{P}$ transport in surface runoff, subsurface runoff, and sediments of purple soil under simulated rainfall. The objectives of this research are as follows: (1) to understand the effect of slope gradient on surface runoff, subsurface runoff, and sediment loss; (2) to gain insight into the effect of slope gradients on forms of $\mathrm{P}$ loss; and (3) to assess the influence of different slope gradients on the relationships among forms of $\mathrm{P}$, runoff, and sediment.

\section{Materials and Methods}

\section{Study Site}

The experimental field is located in the upper reaches of the Huajiao River, Songtao, Ziyang in the Tuo River system of the Yangtze River (104'34'12"$104^{\circ} 35^{\prime} 19^{\prime \prime} \mathrm{E}$ and $\left.30^{\circ} 05^{\prime} 12^{\prime \prime}-30^{\circ} 06^{\prime} 44^{\prime \prime} \mathrm{N}\right)$ at an elevation of $395 \mathrm{~m}$ (Fig. 1). The average annual rainfall is 965.8 $\mathrm{mm}$, and rainstorms often occur from June to October. The average annual temperature is $16.8^{\circ} \mathrm{C}$. The area is dominated by purple soils formed in Purple sandy shale, classified as Entisol according to the soil taxonomy of the United States Department of Agriculture [19]. Soil physical-chemical properties are listed in Table 1.

\section{Rainfall Simulator}

The simulator was programmed and equipped with two spray nozzles (SR). SRs were of the V-80100
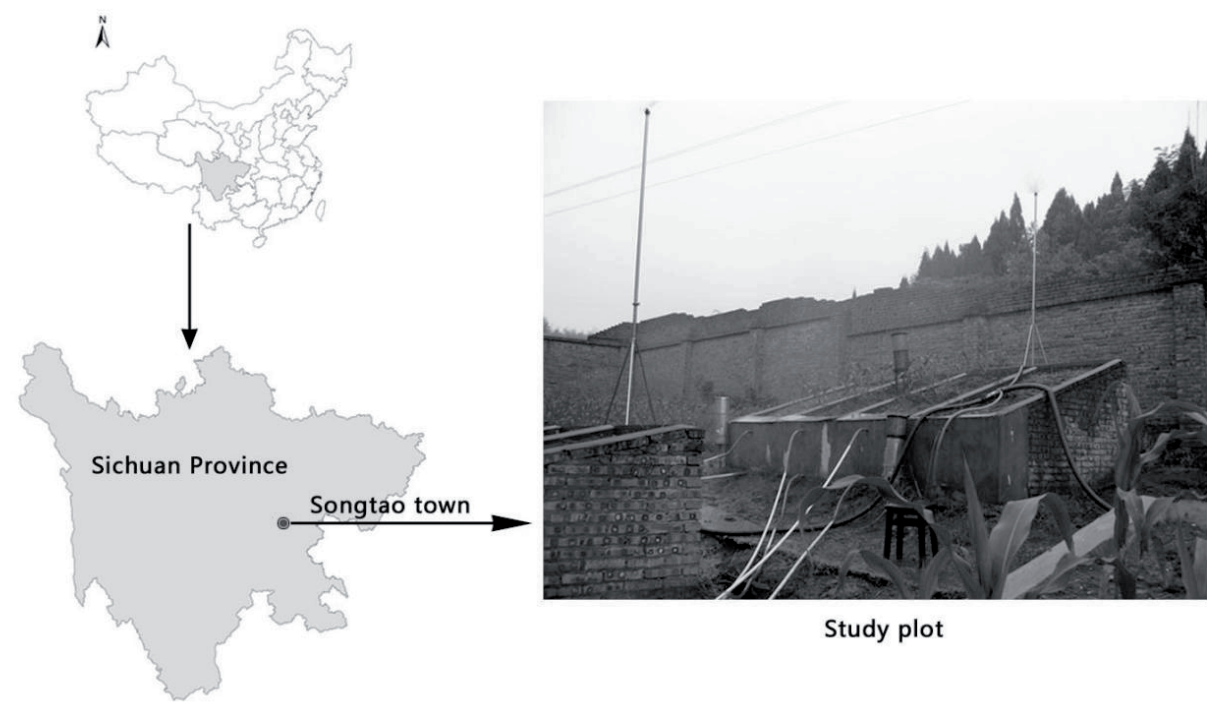

Fig. 1. Study plot location in the Songtaotown of Sichuan Province. 
Table 1. Soil physical and chemical properties.

\begin{tabular}{|c|c|c|c|c|c|c|c|}
\hline $\mathrm{pH}$ & $\begin{array}{c}\text { Organic } \\
\text { Matter } \\
\left(\mathrm{gkg}^{-1}\right)\end{array}$ & $\begin{array}{c}\text { Total } \\
\text { Nitrogen } \\
\left(\mathrm{gkg}^{-1}\right)\end{array}$ & $\begin{array}{c}\text { Total } \\
\text { Phosphorus } \\
\left(\mathrm{gkg}^{-1}\right)\end{array}$ & $\begin{array}{c}\text { Total Potassium } \\
\left(\mathrm{gkg}^{-1}\right)\end{array}$ & $\begin{array}{c}\text { Available } \\
\text { Nitrogen } \\
\left(\mathrm{mgkg}^{-1}\right)\end{array}$ & $\begin{array}{c}\text { Available } \\
\text { Phosphorus } \\
\left(\mathrm{mgkg}^{-1}\right)\end{array}$ & $\begin{array}{c}\text { Available } \\
\text { Potassium } \\
\left(\mathrm{mgkg}^{-1}\right)\end{array}$ \\
\hline 8.1 & 7.34 & 0.91 & 0.80 & 18.80 & 100.36 & 6.26 & 134 \\
\hline
\end{tabular}

series and installed by the Institute of Soil and Water Conservation, Chinese Academy of Sciences. The operating pressures ranged from 0 to 5.0 bar. The height of the rainfall simulator was $7 \mathrm{~m}$, and the effective rainfall area was approximately $5 \mathrm{~m} \times 6 \mathrm{~m}$. The simulator had an approximate rainfall uniformity of $90 \%$. In this study, the simulated rainfall intensity was $2.0 \mathrm{~mm} \cdot \mathrm{min}^{-1}$ for $30 \mathrm{~min}$, according to the characteristics of local storms, which are most prevalent in spring and summer in the study area. The rainfall simulation experiments were repeated three times for every slope gradient.

\section{Experimental Setup and Sample Collection}

According to the local conditions, 40000 plants of the staple crop maize (Chuandan 13) were cultivated in a $1-\mathrm{hm}^{2}$ area, and row and plant spaces were 80 and $25 \mathrm{~cm}$, respectively. Nitrogen $(\mathrm{N})$, phosphate $\left(\mathrm{P}_{2} \mathrm{O}_{5}\right)$, and potash $\left(\mathrm{K}_{2} \mathrm{O}\right)$ fertilizers were applied at rates of 250 , 125 , and $150 \mathrm{~kg} \cdot \mathrm{hm}^{-2}$, respectively, before sowing. The $\mathrm{N}$ fertilizer was urea $(46.3 \% \mathrm{~N})$; the $\mathrm{P}$ fertilizer was calcium superphosphate $\left(12 \% \mathrm{P}_{2} \mathrm{O}_{5}\right)$; and the $\mathrm{K}$ fertilizer was potassium chloride $\left(60 \% \mathrm{~K}_{2} \mathrm{O}\right)$. Other management measures were all based on local farming practices.

The slope system consisted of soil micro plots measuring $2 \mathrm{~m} \times 1 \mathrm{~m} \times 0.4 \mathrm{~m}$ (length $\times$ width $\times$ height) The simulation rainfall experiments were conducted on three slope gradients $\left(10^{\circ}, 15^{\circ}, 20^{\circ}\right)$. The bottom of each plot was reinforced by concrete to facilitate the formation of a relatively impermeable layer, which coincides with the slope gradient of the soil surface. The surface runoff, moving down the inclined surface soil toward every plot, was drained through an outlet into a concrete pond. The subsurface runoff reached the impermeable layer through small holes of $2 \mathrm{~cm}$ diameter on the flapper, and a PVC pipe was used to connect the tank and the runoff collection barrel. According to local farming methods, this study used flat planting as a tillage measure. Each treatment was repeated three times, and a total of nine plots were used. The experiment was conducted during the maize seedling stage.

\section{Sample Extraction, Cleanup, and Analysis}

Runoff-yield time was accurately recorded after the rainfall-runoff process. Surface runoff was collected in plastic buckets every three minutes. The entire subsurface runoff samples were collected in plastic buckets. Runoff samples were collected in $200 \mathrm{~mL}$ plastic bottles, to which $0.5 \mathrm{~mL}$ of $98 \% \mathrm{H}_{2} \mathrm{SO}_{4}$ was added to reduce microbial activity. The runoff samples were taken back to the laboratory and frozen $\left(-4^{\circ} \mathrm{C}\right)$ for immediate analysis. The sediment samples were ovendried $\left(105^{\circ} \mathrm{C}\right)$ and passed through $2 \mathrm{~mm}$ sieves for measurement.

The concentrations of total phosphorus (TP) in runoff were analyzed colorimetrically at $700 \mathrm{~nm}$ with a spectrophotometer. The runoff samples were passed through a $0.45 \mu \mathrm{m}$ filter, and subsamples were analyzed colorimetrically for dissolved total phosphorus (DTP). TP comprised particulate phosphorus (PP) and DTP; PP was calculated by subtracting DTP from TP [20].

To evaluate the controllability of soluble $\mathrm{P}$ losses in surface runoff treated by agricultural practices, we computed the losses of various types of $\mathrm{P}$ on the runoff and sediment from each plot. The total nutrient losses were estimated as the sum of these precipitation event values. The TP, DTP, PP and AP losses (Q) under a rainstorm event were the same as in [21].

$$
Q=\sum_{i=1}^{n} C_{i} \times q_{i}
$$

...where $\mathrm{C}_{\mathrm{i}}$ is the TP, DTP or PP concentration in the runoff $\left(\mathrm{mg} \mathrm{L}^{-1}\right)$, and AP concentration in the sediment (mg kg-1); and $q_{i}$ is the runoff discharge $\left(\mathrm{L} \mathrm{m}^{-2}\right)$ or sediment discharge $\left(\mathrm{gm}^{-2}\right)$. $(i=1$ to $n$, the number of runoff and sediment collected throughout the period of the simulated rainfall event).

\section{Statistical Analysis}

SPSS 20.0 and Excel 2016 software were used for the statistical analyses and figure preparations, respectively. Results were expressed as mean \pm standard error of the mean.

\section{Results}

\section{Characteristics of Runoff and Sediment Yield}

The variation of runoff involves complex processes with respect to changing slope gradient. The amount of runoff mainly depends on the accumulating infiltration volume and the volume of rainfall accommodated by the soil. Considering a short-term heavy rainfall, the surface runoff-yield time under different slope gradients were around $3.5 \mathrm{~min}$. The runoff exhibited indistinguishable discrepancies on different slope gradients (Fig. 2). Runoff generation increased with the extension of the 


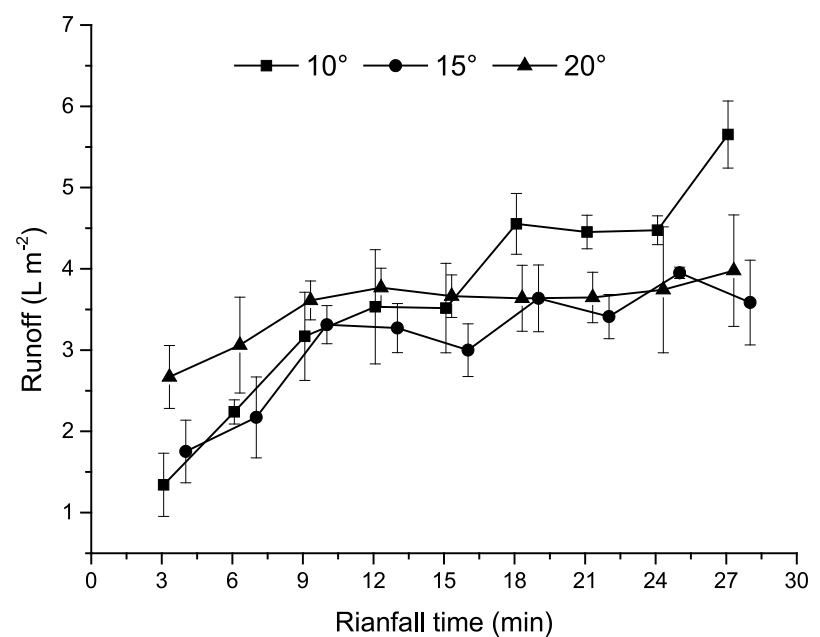

Fig. 2. Dynamic variation characteristics of surface runoff on different slope gradients.

rainfall duration. The increasing range of runoff was larger during the first 10 min of rainfall events. Runoff yield on the $10^{\circ}$-slope farmland displayed an increasing trend during the rainfall events, whereas those of $15^{\circ}$ and $20^{\circ}$-slopes were almost steady during the later period of rainfall events. After $15 \mathrm{~min}$ of rainfall, the $15^{\circ}$-and $20^{\circ}$-slopes exhibited less runoff generation within a $7 \%$ to $36 \%$ decreasing range compared to the $10^{\circ}$-slope. Results indicated relatively complex influences of slope changes on runoff-yield under short-term heavy rainfall events. Runoff generation did not increase with increasing slope gradients and was greater on gentle slopes than those of the other conditions.

The sediment increased with the extension of rainfall duration (Fig. 3). Sediment yield on the $10^{\circ}$-slope increased steadily at the earlier stage of rainfall, then fluctuated after $18 \mathrm{~min}$, the range of variation was between $10.66-61.38 \mathrm{~g} \cdot \mathrm{m}^{-2}$. Sediment yield

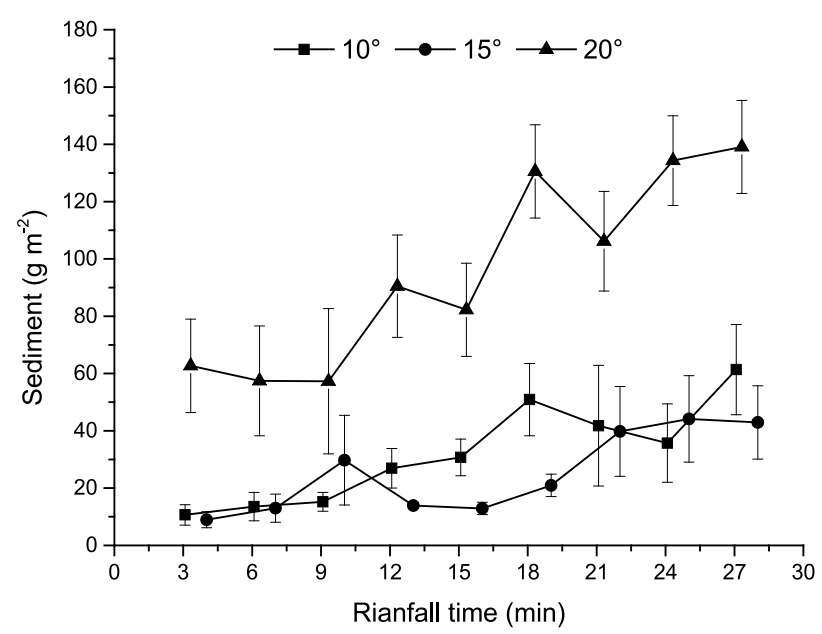

Fig. 3. Dynamic variation characteristics of sediments on different slope gradients.

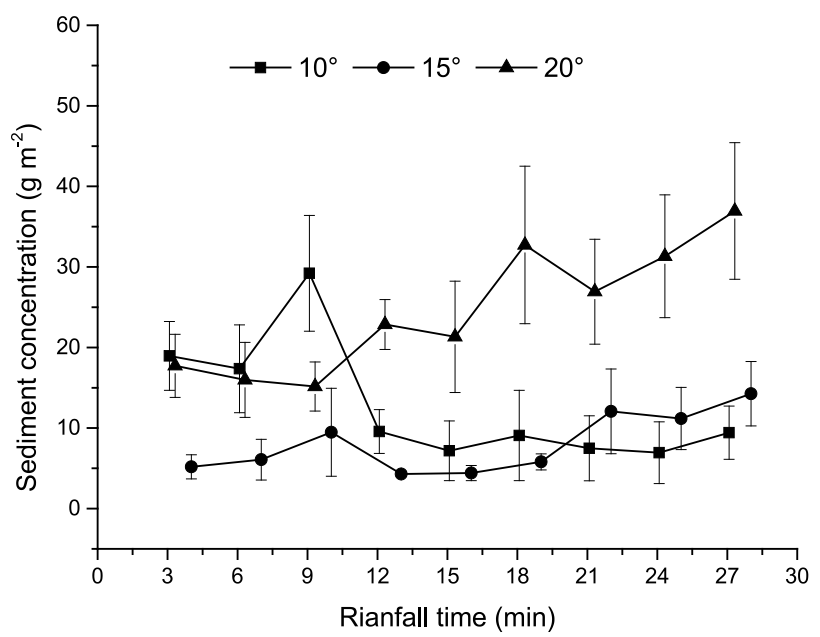

Fig. 4. Dynamic variation characteristics of sediment concentrations on different slope gradients.

on the $15^{\circ}$-slope slowly increased in a wavelike pattern, with a range of variation between 8.94-44.15 $\mathrm{g} \cdot \mathrm{m}^{-2}$. Sediment yield on the $20^{\circ}$-slope increased similarly to a zigzag pattern, and the range of variation was between 57.29-139.09 $\mathrm{g} \cdot \mathrm{m}^{-2}$. The sediment volume on the $20^{\circ}$-slope was significantly higher than those on the $10^{\circ}$-and $15^{\circ}$-slopes, and sediment yields on the $20^{\circ}$-slope were 2.2-5.8 and 1.9-7.0 times those of on the $10^{\circ}$-and $15^{\circ}$-slopes, respectively.

During the initial runoff-yielding period, the sediment concentration was at a minimum of $5.19 \mathrm{~g} \cdot \mathrm{L}^{-1}$ on the $15^{\circ}$-slope (Fig. 4). Meanwhile, sediment concentrations of the $10^{\circ}$-and $20^{\circ}$-slopes were 18.95 and $17.73 \mathrm{~g} \cdot \mathrm{L}^{-1}$, respectively, which were significantly higher than those of the $15^{\circ}$-slope. Sediment concentration and amount of sediment loss exhibited variable trends, which were comparatively consistent with the extension of rainfall events. The sediment concentration on the $10^{\circ}$-slope peaked at around $9 \mathrm{~min}$ and then gradually decreased and stabilized in the later period. The initial sediment concentration on the $10^{\circ}$ slope was higher than that at the end of rainfall simulation.

There was no significant difference for the total of surface runoff between different slope gradients The total of subsurface runoff increased with increasing slope gradients (Table 2). Monolithic subsurface runoff generation was less than that of surface runoff. Subsurface runoff on $10^{\circ}-, 15^{\circ}$-, and $20^{\circ}$-slopes respectively accounted for $13 \%, 20 \%$, and $28 \%$ of total runoff. When the slope gradient was relatively gradual, the component force of gravity had little influence on water infiltrating the soil. Thus, most water was intercepted in the soil body, and only a small portion of runoff flowed out as macropore flow. The $10^{\circ}$ - and $15^{\circ}$ - slopes did not show significant differences in total sediment.The $20^{\circ}$-slope exhibited the maximum amount of sediment, which was 3.2 and 3.8 times those of the $10^{\circ}$-and $15^{\circ}$-slopes, correspondingly. The soil body vulnerability was augmented when the slope gradient 
Table 2. Characteristics of total runoff on different slopes gradients.

\begin{tabular}{|c|c|c|c|}
\hline \multirow{2}{*}{ Slope gradient } & \multicolumn{2}{|c|}{ Total of runoff $\left(\mathrm{Lm}^{-2}\right)$} & \multirow{2}{*}{ Sediment $\left(\mathrm{gm}^{-2}\right)$} \\
\cline { 2 - 4 } & Surface runoff & Subsurface runoff & $266.43 \pm 176.28$ \\
\hline $10^{\circ}$ & $31.05 \pm 11.43$ & $4.71 \pm 0.83$ & $226.34 \pm 68.62$ \\
\hline $15^{\circ}$ & $28.09 \pm 2.10$ & $6.96 \pm 2.41$ & $860.24 \pm 328.55$ \\
\hline $20^{\circ}$ & $31.78 \pm 4.01$ & $12.40 \pm 2.28$ & \\
\hline
\end{tabular}

increased, and the possibility of sediment migration increased with runoff movement. Thus, the $20^{\circ}$-slope has greater propensity for erosion than the $10^{\circ}$-and $15^{\circ}$-slopes.

\section{Characteristics of P Loss by Runoff}

TP concentration decreased with the extension of rainfall duration (Fig. 5). The $20^{\circ}$-slope had a smaller range of variation than those of the $10^{\circ}$-and $15^{\circ}$-slopes. The mean concentrations of TP were $0.16,0.18$, and $0.08 \mathrm{mg} \cdot \mathrm{L}^{-1}$ on $10^{\circ}-, 15^{\circ}$-, and $20^{\circ}$-slopes, respectively. The TP concentration in runoff on the $20^{\circ}$-slope accounted for $49 \%$ and $43 \%$ of that on $10^{\circ}$-and $15^{\circ}$-slopes, respectively. This observation may be attributed to rapid runoff yield when the slope was relatively large and there was only a short period for mutual effects between water and soil, causing a smaller amount of $\mathrm{P}$ to be released. The amount of TP loss was influenced by both runoff and $\mathrm{P}$ concentration. The different slopes exhibited relatively larger ranges of TP loss at the beginning of the rainfall process; ranges fluctuated after $6 \mathrm{~min}$. The TP loss peaked at $12 \mathrm{~min}$ on every plot. The amounts of TP loss at the end of rainfall simulation were higher than the initial figures. TP loss amounts were higher at the start of the rainfall and stabilized afterward. Therefore, preventing P losses at the initial stage of rainfall could reduce loss of $\mathrm{P}$ from the soil. On the $20^{\circ}$-slope, the amount of TP loss was less than those of the other slopes.

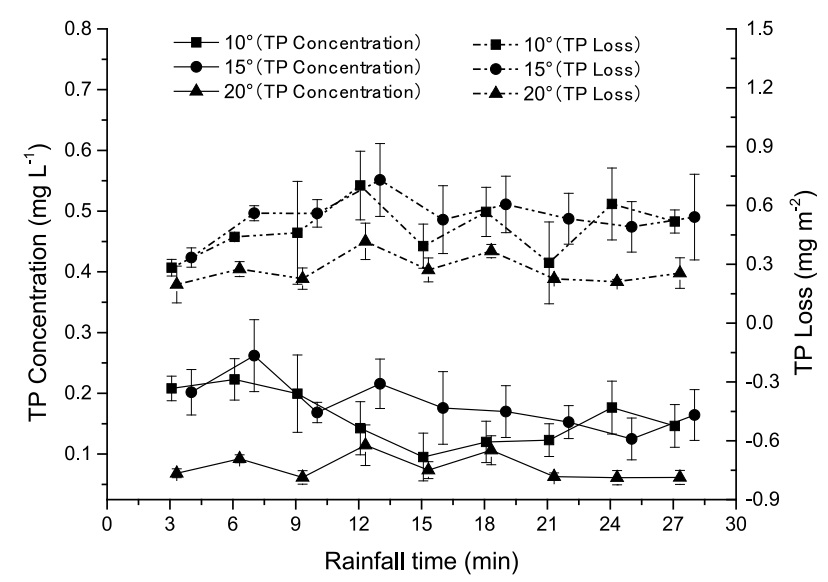

Fig. 5. Characteristics of TP concentration and loss in the surface runoff on different slope gradients.
DTP is related to specific adsorption of soil particles. It was desorbed from soil particles and then flowed away with the dissolution and scouring action of runoff. In general, the absorption-desorption between DTP and runoff and sediment occurs throughout the whole erosion process. Characteristics of DTP concentration and loss amount were similar to variation characteristics of TP (Fig. 6). The concentration and loss amount of DTP on the $20^{\circ}$-slope were lower than those of other slope gradients. DTP concentrations on $10^{\circ}$-, $15^{\circ}$-, and $20^{\circ}$-slopes comprised 55-94\%, 73-93\%, and $64-91 \%$ of TP concentrations, respectively. Thus DTP concentrations dominated $\mathrm{P}$ concentrations in runoff. Moreover, slope gradient variations had little influence on PP concentration in runoff, and variation ranges on different slope gradients were minor during the entire runoff yield (Fig. 7). The DTP loss amount constantly increased on the $10^{\circ}$-slope, whereas those of on $15^{\circ}$-and $20^{\circ}$-slopes were reduced during the later period of the rainfall events. PP accounted for a significantly smaller percentage than DTP.

TP loss load was a primary indicator for evaluating $\mathrm{P}$ losses on different slope gradients during rainfall events, because it showed direct significance in preventing $\mathrm{P}$ losses. The loss amounts of different $\mathrm{P}$ forms in surface runoff increased and then decreased with increasing slope gradients (Table 3). Although minor differences were noted among slope gradients, as for mean values, $\mathrm{P}$ loss load on the $15^{\circ}$-slope was

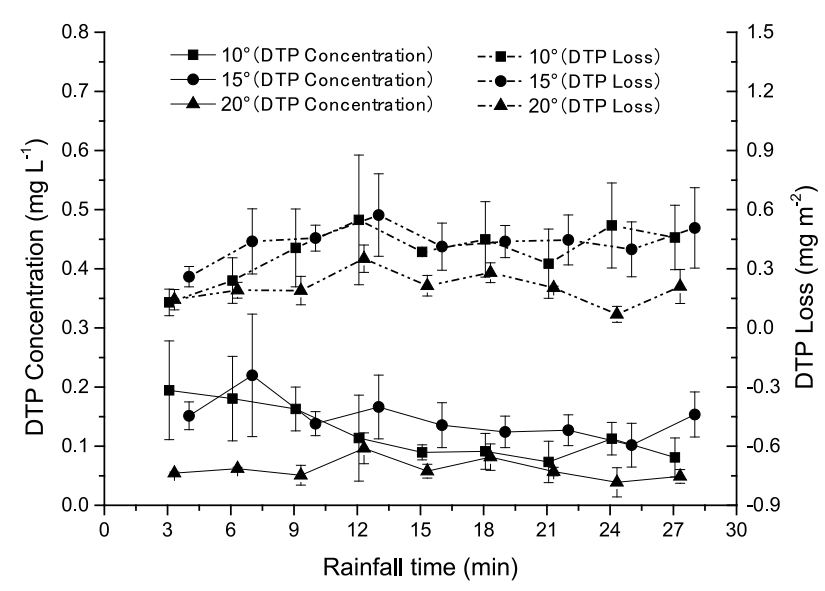

Fig. 6. Characteristics of DTP concentration and loss in the surface runoff on different slope gradients. 


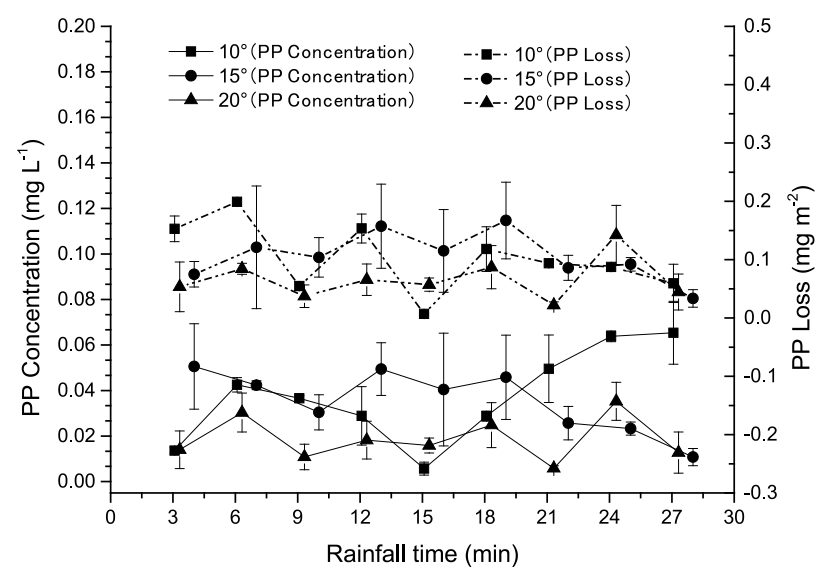

Fig. 7. Characteristics of PP concentration and loss in the surface runoff on different slope gradients.

highest and close to that of the $10^{\circ}$-slope. The $\mathrm{P}$ loss load on the $20^{\circ}$ slope was significantly less than that of the other two gradients. TP and DTP loss amounts in surface runoff on $10^{\circ}$-slope were significantly less than those of $15^{\circ}$ - and $20^{\circ}$ - slopes. The PP loss had little differences among the different slope gradients, and $\mathrm{P}$ loss load in the subsurface runoff was less than that in the surface runoff. As for proportions of different $\mathrm{P}$ forms, DTP loss accounted for $81 \%, 81 \%$, and $76 \%$ of TP loss amounts in surface runoff on the $10^{\circ}-, 15^{\circ}$-, and $20^{\circ}$-slopes, respectively. the proportions of which were $54 \%, 89 \%$, and $66 \%$ in subsurface runoff on the $10^{\circ}$-, $15^{\circ}$-, and $20^{\circ}$-slopes, respectively. $\mathrm{P}$ losses during runoff were based on whether DTP losses were observed in the surface or subsurface runoff.

\section{Characteristics of AP Loss by Sediment Yield}

Available phosphorus (AP) in sediments were washed away by runoff with reduced soil fertility. The AP reduction has a negative influence on plant growth. AP concentrations on different slopes exhibited fluctuating and interlocking decreasing trends (Fig. 8). The mean AP concentrations on $10^{\circ}-, 15^{\circ}$-, and $20^{\circ}$-slopes were 21.28, 21.28, and $21.90 \mathrm{mg} \cdot \mathrm{kg}^{-1}$, respectively. There was no difference between three slope gradients $(p<0.05)$. AP loss amounts increased with increasing slope gradient, and on the $10^{\circ}$ - and $15^{\circ}$-slopes, with a variation of $0.11-0.44$ and $0.20-0.80 \mathrm{mg} \cdot \mathrm{m}^{-2}$, respectively, decreased with the extension of rainfall duration; both

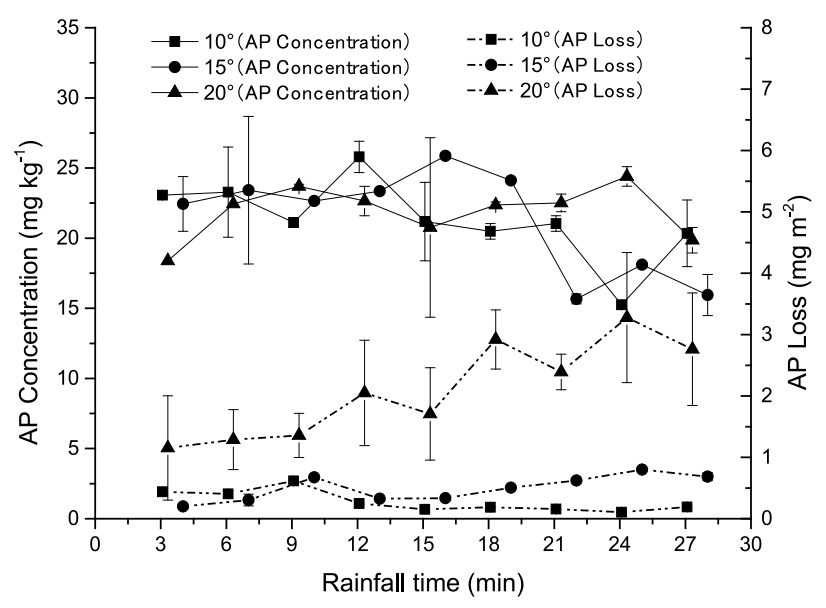

Fig. 8. Characteristics of AP concentration and loss in sediment on different slope gradients.

sets of values peaked successively at around $10 \mathrm{~min}$ and before showing constant variation. AP concentrations on the $20^{\circ}$-slope increased in a zigzag pattern, with a variation of $1.15-3.28 \mathrm{mg} \cdot \mathrm{m}^{-2}$. Furthermore, the AP loss amount of the $20^{\circ}$-slope was much greater than those of $10^{\circ}$-and $15^{\circ}$-slopes. Therefore, slope gradients had little influence on AP concentrations but a significant effect on AP loss amounts. AP loss amounts continually rose with increasing slope gradients (Fig. 9). The AP loss amounts on the $20^{\circ}$-slope were 7.6 and 4.2 times greater than those on the $10^{\circ}$-and $15^{\circ}$-slopes, respectively.

\section{Analysis of Correlations Among Runoff, Sediment Yield, and Losses of Different P Forms}

$\mathrm{P}$ losses are mainly generated by runoff and sediment yield during rainfalls. There was a highly significant positive correlation between runoff and sediment amounts on the $10^{\circ}$-slope (Table 4). AP loss amounts in sediment were prominently influenced by sediment concentration, presenting an extremely significant positive correlation. DTP concentration in runoff were affected by runoff and sediment. The TP concentration had a highly significant negative correlation with runoff and sediment. Therefore, DTP release was seriously influenced by runoff and sediment yield. The AP loss in sediment on the $15^{\circ}$-slope was significantly influenced by sediment (Table 5). TP concentration and sediment quantity in runoff had an extremely remarkable positive correlation with AP loss amounts. DTP concentration

Table 3. Characteristics of total P loss in runoff on different slope gradients.

\begin{tabular}{|c|c|c|c|c|c|c|}
\hline \multirow{2}{*}{ Slope gradient } & \multicolumn{2}{|c|}{ Total of P loss in surface runoff $\left(\mathrm{mg} \mathrm{m}^{-2}\right)$} & \multicolumn{3}{|c|}{ Total of P loss in subsurface runoff $\left(\mathrm{mg} \mathrm{m}^{-2}\right)$} \\
\cline { 2 - 7 } & TP & DTP & PP & TP & DTP & PP \\
\hline $10^{\circ}$ & $4.28 \pm 1.49$ & $3.46 \pm 1.25$ & $0.81 \pm 0.24$ & $0.48 \pm 0.15$ & $0.26 \pm 0.02$ & $0.22 \pm 0.17$ \\
\hline $15^{\circ}$ & $4.88 \pm 1.03$ & $3.93 \pm 0.93$ & $0.95 \pm 0.13$ & $1.83 \pm 1.03$ & $1.63 \pm 1.05$ & $0.20 \pm 0.05$ \\
\hline $20^{\circ}$ & $2.45 \pm 0.27$ & $1.85 \pm 0.19$ & $0.59 \pm 0.10$ & $1.98 \pm 0.74$ & $1.31 \pm 0.22$ & $0.66 \pm 0.53$ \\
\hline
\end{tabular}




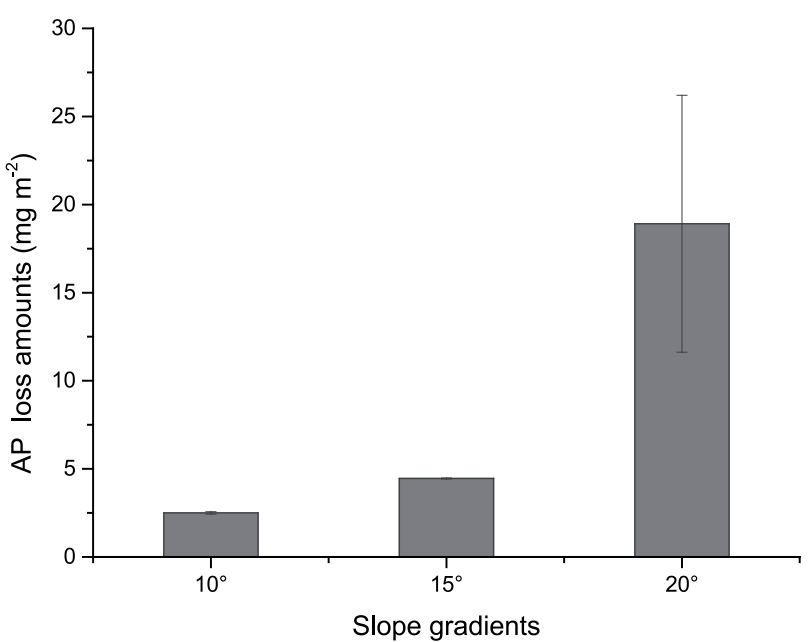

Fig. 9. Characteristics of total AP loss in sediment on different slope gradients.

and loss load were largely affected by TP concentration and loss amounts. PP concentration showed very notable positive correlations with sediment quantity, sediment concentration, and AP concentration. On the $20^{\circ}$-slope, highly significant correlations were noted among sediment quantity, sediment concentration, and AP losses (Table 6). TP loss amounts were closely related with runoff concentration. DTP concentration and loss amounts were greatly influenced by TP. The PP loss load had a very notable positive correlation only with PP concentration. In conclusion, P losses on various slope surfaces have complex relationships with runoff-sediment-yield and different forms of $P$. Thus, controlling soil and water losses is important in alleviating P losses on slope farmlands.
Discussion

Runoff caused by rainfalls carries $\mathrm{N}$ and $\mathrm{P}$ nutrients from soil to water bodies, it can cause not only reduction of fertilizer use efficiency but also water eutrophication [22-24]. Purple soil is loose on slope farmlands during the maize seedling stage, which easily leads to severe soil erosion and $\mathrm{P}$ loss during rainfall events. $\mathrm{P}$ loss on slope farmlands depends on two aspects: one is P loss in runoff, and the other is P loss in sediment. This study set the rainfall intensity at $2.0 \mathrm{~mm} \cdot \mathrm{min}^{-1}$ and rainfall duration at $30 \mathrm{~min}$, which was considered a short-term heavy rainfall. The variation tendency of runoff weakened as slope gradient increased, and this weakening was mainly determined by the extent of transfer between rainfall volume and accumulation infiltration volume. Such findings were consistent with the research results of He et al. [13]. Soil particle transfer from the slope is a dynamic development influenced by many factors such as runoff characteristics, soil characteristics, and slope characteristics. Sediment concentration of slope runoff represents the transferability of soil. A much higher sediment concentration causes more serious erosion runoff [25-26]. The sediment concentrations in runoff on $10^{\circ}$-and $20^{\circ}$-slopes were higher than that of the $15^{\circ}$-slope during the early stage of rainfall events. However, sediment concentrations continually increased with increasing slope gradients during the later period of rainfall events. Possibly, the runoff yield of purple soil under saturated storage and much more runoff infiltrating soils during the earlier period of rainfall.

Runoff yield on slopes was complex and influenced by soil structure, infiltration rate, and vegetation coverage. Thus, runoff volumes on the $10^{\circ}$-and $20^{\circ}$-slopes were higher than that of the $15^{\circ}$-slope. However, the soil water was saturated, and this process

Table 4. Correlation coefficient between runoff, sediment and phosphorus on the $10^{\circ}$ slope.

\begin{tabular}{|c|c|c|c|c|c|c|c|c|c|c|c|}
\hline & $\mathrm{R}$ & $\mathrm{S}$ & $\mathrm{C}_{\mathrm{S}}$ & $\mathrm{C}_{\mathrm{AP}}$ & $\mathrm{L}_{\mathrm{AP}}$ & $\mathrm{C}_{\mathrm{TP}}$ & $\mathrm{L}_{\mathrm{TP}}$ & $\mathrm{C}_{\mathrm{DTP}}$ & $\mathrm{L}_{\mathrm{DTP}}$ & $\mathrm{C}_{\mathrm{PP}}$ & $\mathrm{L}_{\mathrm{PP}}$ \\
\hline $\mathrm{R}$ & - & $0.93 * *$ & -0.59 & -0.5 & $-0.66^{*}$ & -0.61 & 0.44 & $-0.88^{* *}$ & $0.73 *$ & $0.70^{*}$ & -0.52 \\
\hline $\mathrm{S}$ & & - & $-0.67 *$ & -0.41 & $-0.72 *$ & $-0.66^{*}$ & 0.31 & $-0.87 * *$ & 0.55 & 0.56 & -0.42 \\
\hline $\mathrm{C}_{\mathrm{S}}$ & & & - & 0.27 & $0.99 * *$ & $0.72 *$ & -0.27 & $0.78^{* *}$ & -0.41 & -0.18 & 0.24 \\
\hline $\mathrm{C}_{\mathrm{AP}}$ & & & & - & 0.4 & 0.05 & -0.09 & 0.32 & -0.3 & -0.51 & 0.39 \\
\hline $\mathrm{L}_{\mathrm{AP}}$ & & & & & - & $0.72 *$ & -0.27 & $0.82 * *$ & -0.46 & -0.25 & 0.32 \\
\hline $\mathrm{C}_{\mathrm{TP}}$ & & & & & & - & -0.14 & $0.89 * *$ & -0.48 & 0.08 & 0.6 \\
\hline $\mathrm{L}_{\mathrm{TP}}$ & & & & & & & - & -0.28 & $0.86 * *$ & 0.34 & 0.31 \\
\hline $\mathrm{C}_{\mathrm{DTP}}$ & & & & & & & & - & $-0.64 *$ & -0.37 & $0.65 *$ \\
\hline $\mathrm{L}_{\mathrm{DTP}}$ & & & & & & & & & - & 0.44 & -0.22 \\
\hline $\mathrm{C}_{\mathrm{PP}}$ & & & & & & & & & & & -0.2 \\
\hline $\mathrm{L}_{\mathrm{PP}}$ & & & & & & & & & & & \\
\hline
\end{tabular}

Note: R-Runoff, S-Sediment, C-Concentration, L- Loss amount 
Table 5. Correlation coefficient between runoff, sediment and phosphorus on the $15^{\circ}$ slope.

\begin{tabular}{|c|c|c|c|c|c|c|c|c|c|c|c|}
\hline & $\mathrm{R}$ & $\mathrm{S}$ & $\mathrm{C}_{\mathrm{S}}$ & $\mathrm{C}_{\mathrm{AP}}$ & $\mathrm{L}_{\mathrm{AP}}$ & $\mathrm{C}_{\mathrm{TP}}$ & $\mathrm{L}_{\mathrm{TP}}$ & $\mathrm{C}_{\mathrm{DTP}}$ & $\mathrm{L}_{\mathrm{DTP}}$ & $\mathrm{C}_{\mathrm{PP}}$ & $\mathrm{L}_{\mathrm{PP}}$ \\
\hline $\mathrm{R}$ & - & $0.74^{*}$ & 0.53 & -0.41 & $0.83^{* *}$ & $-0.73^{*}$ & 0.49 & $-0.65^{*}$ & 0.57 & -0.52 & 0.09 \\
\hline $\mathrm{S}$ & & - & $0.95^{* *}$ & $-0.87 * *$ & $0.95^{* *}$ & $-0.79 * *$ & -0.01 & -0.55 & 0.27 & $-0.88^{* *}$ & -0.52 \\
\hline $\mathrm{C}_{\mathrm{S}}$ & & & - & $-0.92^{* *}$ & $0.84^{* *}$ & $-0.65^{*}$ & -0.14 & -0.36 & 0.2 & $-0.92^{* *}$ & $-0.71 *$ \\
\hline $\mathrm{C}_{\mathrm{AP}}$ & & & & - & $-0.68^{*}$ & 0.57 & 0.19 & 0.31 & -0.14 & $0.77 * *$ & $0.68^{*}$ \\
\hline $\mathrm{L}_{\mathrm{AP}}$ & & & & & - & $-0.81 * *$ & 0.08 & -0.62 & 0.29 & $-0.80^{* *}$ & -0.34 \\
\hline $\mathrm{C}_{\mathrm{TP}}$ & & & & & & - & 0.21 & $0.94 * *$ & 0.08 & 0.59 & 0.35 \\
\hline $\mathrm{L}_{\mathrm{TP}}$ & & & & & & & - & 0.2 & $0.92 * *$ & 0.12 & $0.64 *$ \\
\hline $\mathrm{C}_{\mathrm{DTP}}$ & & & & & & & & - & 0.19 & 0.28 & 0.1 \\
\hline $\mathrm{L}_{\mathrm{DTP}}$ & & & & & & & & & - & -0.23 & 0.28 \\
\hline $\mathrm{C}_{\mathrm{PP}}$ & & & & & & & & & & - & $0.73 *$ \\
\hline $\mathrm{L}_{\mathrm{PP}}$ & & & & & & & & & & \\
\hline
\end{tabular}

$* \mathrm{p}<0.05 \quad * * \mathrm{p}<0.01$

Note: R-Runoff, S-Sediment, C-Concentration, L- Loss amount.

Table 6. Correlation coefficient between runoff, sediment and phosphorus on the $20^{\circ}$ slope.

\begin{tabular}{|c|c|c|c|c|c|c|c|c|c|c|c|}
\hline & $\mathrm{R}$ & $\mathrm{S}$ & $\mathrm{C}_{\mathrm{S}}$ & $\mathrm{C}_{\mathrm{AP}}$ & $\mathrm{L}_{\mathrm{AP}}$ & $\mathrm{C}_{\mathrm{TP}}$ & $\mathrm{L}_{\mathrm{TP}}$ & $\mathrm{C}_{\mathrm{DTP}}$ & $\mathrm{L}_{\mathrm{DTP}}$ & $\mathrm{C}_{\mathrm{PP}}$ & $\mathrm{L}_{\mathrm{PP}}$ \\
\hline $\mathrm{R}$ & - & $0.67^{*}$ & $0.65^{*}$ & 0.43 & $0.69^{*}$ & -0.06 & 0.3 & 0.18 & 0.31 & 0.05 & 0.05 \\
\hline $\mathrm{S}$ & & - & $0.99^{* *}$ & 0.13 & $0.97^{* *}$ & -0.02 & 0.13 & 0 & 0 & 0.2 & 0.33 \\
\hline $\mathrm{C}_{\mathrm{S}}$ & & & - & 0.01 & $0.93^{* *}$ & -0.03 & 0.12 & 0 & 0.04 & 0.1 & 0.23 \\
\hline $\mathrm{C}_{\mathrm{AP}}$ & & & & - & 0.35 & 0.1 & 0.18 & 0.1 & -0.02 & 0.54 & 0.46 \\
\hline $\mathrm{L}_{\mathrm{AP}}$ & & & & & - & 0 & 0.14 & 0.01 & -0.04 & 0.35 & 0.46 \\
\hline $\mathrm{C}_{\mathrm{TP}}$ & & & & & & - & $0.92^{* *}$ & $0.88^{* *}$ & $0.75^{*}$ & 0.2 & 0.28 \\
\hline $\mathrm{L}_{\mathrm{TP}}$ & & & & & & & - & $0.96^{* *}$ & $0.90^{* *}$ & 0.1 & 0.15 \\
\hline $\mathrm{C}_{\mathrm{DTP}}$ & & & & & & & & - & $0.93 * *$ & -0.06 & -0.03 \\
\hline $\mathrm{L}_{\mathrm{DTP}}$ & & & & & & & & & - & -0.31 & -0.28 \\
\hline $\mathrm{C}_{\mathrm{PP}}$ & & & & & & & & & & - & $0.92 * *$ \\
\hline $\mathrm{L}_{\mathrm{PP}}$ & & & & & & & & & & & - \\
\hline $\mathrm{P}<0.05$
\end{tabular}

$* \mathrm{p}<0.05 \quad * * \mathrm{p}<0.01$

Note: R-Runoff, S-Sediment, C-Concentration, L- Loss amount.

was primarily runoff generation over infiltration during the later period of rainfall. Therefore, slope gradient was the main factor influencing runoff volume. Surface runoff and sediment quantities were higher on the $20^{\circ}$-slope than those of the $10^{\circ}$-and $15^{\circ}$-slopes. The loss amounts of surface runoff and sediment were lower on the $15^{\circ}$-slope than those of $10^{\circ}$-and $20^{\circ}$-slopes. Runoff and sediment yield volume reached a turning point with increasing slope gradients, indicating the existence of a critical slope. These results were consistent with opinions from scholars who studied the effects of slope gradients on runoff and sediment yield [27]. The critical slope gradients may be determined by experimental conditions and underlying surface factors. This study showed that the runoff and sediment yield volumes were lower on the $15^{\circ}$-slope than those of $10^{\circ}$-and $20^{\circ}$-slopes. Therefore, the $15^{\circ}$-slope could be a critical slope gradient on purple soil slope farmland. The results are similar to those found by Zhang et al. [28] studying runoff and soil loss on different slope gradients in southwest China. However, further verification is required regarding the critical slope gradient of the research area. Subsurface runoff volume increased with increasing slope gradients, agreeing with research results from Luo et al. [9]. This study was based on field runoff plot experiments. The study object was maize, and the slope conditions greatly varied; these variables were possible causes of the absence of a critical slope during subsurface runoff 
generation when the slope gradually changed from $10^{\circ}$ to $20^{\circ}$-slopes

The losses of different $\mathrm{P}$ forms in runoff were highest on the $15^{\circ}$-slope, and lowest on the $10^{\circ}$-slope. This trend was completely contrary to the variation trend in runoff volume. P loss load was lowest on the slope with highest runoff volume. As shown in Fig. 2, runoff volume on the $20^{\circ}$-slope was greater than those under other conditions at $0-15 \mathrm{~min}$, though it decreased afterward. As for total amounts, runoff volume on the $20^{\circ}$-slope only increased by 2.4 and $13.1 \%$ compared to those on the $10^{\circ}$-and $15^{\circ}$-slopes, respectively. However, $\mathrm{P}$ concentration in runoff on the $20^{\circ}$ slope was lower than those of $10^{\circ}$-and $15^{\circ}$-slopes during rainfall events (Figs 5-7). Therefore, runoff volume had little influence on $\mathrm{P}$ loss amounts, but was greatly influenced on $\mathrm{P}$ concentration on the $20^{\circ}$ slope. Table 6 showed that the different $\mathrm{P}$ form losses had a remarkable positive correlation with $\mathrm{P}$ concentrations in runoff. There was no significant correlation between $\mathrm{P}$ concentration and runoff volume. Soil has a strong absorption capacity for P. Analysis of TP in the topsoil of plots before rainfall showed the following results: TP concentrations

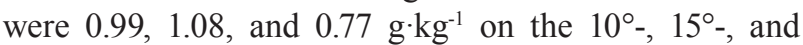
$20^{\circ}$-slopes, respectively. TP concentration in topsoil on the $20^{\circ}$-slope was obviously less than those on $10^{\circ}$ and $15^{\circ}$-slopes, which could be the main reason leading to minor $\mathrm{P}$ loss amounts on the $20^{\circ}$-slope. $\mathrm{P}$ mainly gathers in surface soil, and P loss is influenced by both runoff volume and $\mathrm{P}$ concentration in soil [29-31]. He et al. [32] also pointed out that the TP concentration in topsoil was the main factor affecting $\mathrm{P}$ loss with surface runoff. To control $\mathrm{P}$ losses on slopes, necessary study considerations should include $\mathrm{P}$ concentration in soil and the application amount of $\mathrm{P}$ fertilizer. Blindly applying fertilizer for high yield will cause excess $\mathrm{P}$ in soil, increasing the P load flowing away with soil and water loss.

Originating from purple shale, purple soil has high porosity, powerful infiltration capacity, a shallow soil layer, and weak underlying water permeability. Therefore, macropore flow is easily gathered after runoff yield, thereby forming subsurface runoff [21, 33]. Subsurface runoff volume was less than surface runoff, and continued growing with increasing slope gradient. The subsurface runoff volume accounted for $13 \%, 20 \%$, and $28 \%$ of total runoff volume on $10^{\circ}-, 15^{\circ}$-, and $20^{\circ}$-slopes, respectively, whereas TP loss amounts in subsurface runoff accounted for $10 \%$, $27 \%$, and $45 \%$ of TP loss amounts in total runoff on $10^{\circ}-, 15^{\circ}$-, and $20^{\circ}$-slopes, respectively. Clearly, P losses in subsurface runoff of purple soil farmlands accounted for a considerable proportion of $\mathrm{P}$ losses in runoff from slopes. The TP concentrations in surface runoff were $0.14,0.17$, and $0.08 \mathrm{mg} \cdot \mathrm{L}^{-1}$ on $10^{\circ}-, 15^{\circ}$, and $20^{\circ}$-slopes, respectively, while those in subsurface runoff were $0.10,0.26$, and $0.16 \mathrm{mg} \cdot \mathrm{L}^{-1}$, correspondingly. These observations indicate that TP concentration in subsurface runoff was greater than those of the surface runoff. Moreover, the seedling stage is crucial for the growth of crops. The water and nutrient supplies greatly influence plant growth and development during the same period. Most $\mathrm{P}$ still remains in the soil layers after tillage and fertilization, maintaining the $\mathrm{P}$ concentration in topsoil at high levels [23]. P in the soil is released with the disturbance of runoff to some extent when rainfall occurs. Furthermore, the effects of tillage on soil layers caused the physical environment of the soil to change with respect to soil porosity and relevant aeration conditions. These variations can promote activity of aerobic soil organisms. When this process interacts with the physical destruction of soil structure, some $\mathrm{P}$ in the soil can be released [34]. The slope cropland generated the highest runoff and associated $\mathrm{P}$ loss than those of others land use patterns obtained by Wang et al. [35]. Meanwhile, because the infiltration rate of purple soil is relatively high, water is absorbed by the soil and turns into subsurface runoff. The flow velocity of subsurface runoff accelerates, and the total amounts of subsurface runoff relevantly increase when the slope gradients increases. P loss amounts in subsurface runoff also rise with increasing slope gradient. Therefore, although the proportion of subsurface runoff volume with respect to total runoff was not that high, the $P$ washed away with subsurface runoff cannot be ignored. To control P losses at the maize seedling stage on slope farmland of purple soil, control of the surface runoff and water-holding capacity of the soil should be enhanced in order to reduce the production of subsurface runoff.

\section{Conclusion}

For short-term heavy rainfall, slope changes have relatively complex effects on the runoff yield process. The surface runoff and sediment were highest on the $20^{\circ}$-slope, and were lowest on the $15^{\circ}$-slope. On the contrary, for total subsurface runoff volume, results followed the order of $20^{\circ}->15^{\circ}->10^{\circ}$-slopes. The total losses of different $\mathrm{P}$ forms initially increased and then decreased along with increasing slope gradients. P loss was lowest and runoff was highest on the $20^{\circ}$-slope. P loss in subsurface runoff could not be ignored, although it was less than that in surface runoff.

TP loss amounts in surface runoff had a constantly increasing tendency on the $10^{\circ}$-slope, whereas those on the $15^{\circ}$-and $20^{\circ}$-slopes were reduced during the later period of rainfall simulation. Slope gradients had little influence on AP concentration in sediment but significantly affected AP loss amounts, which continuously grew with increasing slope gradient. Slope gradient variation had little influence on PP concentration in runoff. The DTP loss dominated the TP loss in runoff. DTP loss was greatly influenced by runoff and sediment yield on the $10^{\circ}$-slope, showing a highly significant positive correlation. Highly significant correlations were observed among sediment 
quantity, sediment concentration, and AP losses on the $15^{\circ}$-and $20^{\circ}$-slopes. $\mathrm{P}$ in both runoff and sediment were influenced by sediment yield and sediment concentration. Therefore, controlling soil and water losses is indispensable for alleviating $\mathrm{P}$ losses from slope farmland.

\section{Acknowledgements}

This study was funded by the National Natural Science Foundation of China (grant Nos. 40901138 and 41271307) and as a general project of the Sichuan Provincial Education Department (No. 15ZB0009).

In the manuscript, Xiaoling $\mathrm{He}$, Zicheng Zheng, and Tingxuan $\mathrm{Li}$ implemented experiment design, experiment management, statistical analysis and wrote this paper. Shuqin He contributed reagents, materials, and analysis tools, and reviewed the manuscript.

\section{Conflict of Interest}

The authors declare no conflict of interest.

\section{References}

1. GAO Y., ZHU B., ZHOU P., TANG J.L., WANG T., MIAO C.Y. Effects of vegetation cover on phosphorus loss from a hillslope cropland of purple soil under simulated rainfall, a case study in China. Nute. Cycl. Agroecosyst, 85, 263, 2009.

2. GAO Y., ZHU B., WANG T., TANG J.L., ZHOU P., MIAO C.Y. Bioavaible phosphorus transport from a hillslope cropland of purple soil under natural and simulated rainfall. Environ. Monit. Assess, 171, 539, 2010.

3. YANG J.L., ZHANG G.L., SHI X.Z., WANG H.J., CAO Z.H., RITSEMA C.J. Dynamic changes of nitrogen and phosphorus losses in ephemeral runoff processes by typical storm events in Sichuan Basin, Southwest China. Soil Till Res, 105, 292, 2009.

4. LI G.H., VAN ITTERSUM M.K., LEFFELAAR P.A., SATTARI S.Z., LI H.G., HUANG G.Q., ZHANG F.S. A multi-level analysis of China's phosphorus flows to identify options for improved management in agriculture. Agr. Syst, 144, 87, 2016.

5. SHIPITALO M.J., OWENS L.B., BONTA J.V. Effect of no-till and extended rotationon nutrient losses in surface runoff. Soil Sci. Soc. Am. J, 77, 1329, 2013.

6. GAO Y., ZHU B., YU G.R., CHEN W.L., HE N.P., WANG T., MIAO C.Y. Coupled effects of biogeochemical and hydrological processes on $\mathrm{C}, \mathrm{N}$, and $\mathrm{P}$ export during extreme rainfall events in a purple soil watershed in southwestern China. J Hydrol, 511, 692, 2014.

7. GE F.L., ZHANG J.H., SU Z.G., NIE X.J. Response of changes in soil nutrients to soil erosion on a purple soil of cultivated sloping land. Acta Ecologica Sinica, 27, 459, 2007.

8. HAN J.G., LI Z.B., LI P, TIAN J.L. Nitrogen and phosphorous concentrations in runoff from a purple soil in an agricultural watershed. Agr Water Manage, 97, 757, 2010.
9. LUO C.Y., GAO Y., ZHU B., WANG T. Sprinkler-based rainfall simulation experiments to assess nitrogen and phosphorus losses from a hillslope cropland of purple soil in China. Sustainability of Water Quality and Ecology, 1, 40, 2013.

10. XU P., FU B. The runoff characteristics under simulated rainfall on purple soil sloping cropland. Chin.J.Geochem, 30, 317, 2011.

11. QIAN J., ZHANG L.P., WANG W.Y., LIU Q. Effects of vegetation cover and slope length on nitrogen and phosphorus loss from a sloping land under simulated rainfall. Pol. J. Environ. Stud, 23 (3), 835, 2014.

12. SUN J.M., YU X.X., LI H.Z., CHANG Y., WANG H.N., TU Z.H., LIANG H.R. Simulated erosion using soils from vegetated slopes in the Jiufeng Mountains, China. Catena, 136, 128, 2016.

13. HE J.J., SUN L.Y., GONG H.L., CAI Q.G., JIA L.J. The characteristics of rill development and their effects on runoff and sediment yield under different slope gradients. J Mt Sci-engl, 13 (3), 397, 2016.

14. FU S.H., LIU B.Y., LIU H.P., LI X. The effect of slope on interrill erosion at short slopes. Catena, 84 (1-2), 29, 2011.

15. BOURAIMA A.K., HE B., TIAN T.Q. Runoff, nitrogen $(\mathrm{N})$ and phosphorus (P) losses from purple slope cropland soil under rating fertilization in Three Gorges Region. Environ Sci Pollut R, 23, 4541, 2016.

16. LI S.X., WANG Z.H., LI S.Q., GAO Y.J., TIAN X.H. Effect of plastic sheet mulch, wheat straw mulch, and maize growth on water loss by evaporation in dry land areas of china. Agr Water Manage, 116 (2), 39, 2013.

17. ZHU B., WANG T., YOU X., GAO M.R. Nutrient release from weathering of purplish rocks in the Sichuan Basin, China. Pedosphere, 18 (2), 257, 2008.

18. DING X., XUE Y., LIN M., LIU Y. Effects of precipitation and topography on total phosphorus loss from purple soil. Water, 9, 315, 2017.

19. Soil Survey Staff. Keys to soil taxonomy ( $9^{\text {th }}$ ed.). Washington, D. C: USDA/NRCS. 2003.

20. UUSITALO R., YLI-HALLA M., TURTOLA E. Suspended soil as a source of potentially bioavailable phosphorus in surface runoff waters from clay soils. Water Res, 34, 2477, 2000.

21. ZHOU M.H., ZHU B., KLAUS B., WANG T., WANG T., BERGMANN J., BRÜGGEMANN N., WANGA Z.H., LI T.K. KUANGA F.H. Nitrate leaching, direct and indirect nitrous oxide fluxes from sloping cropland in the purple soil area, southwestern China. Environ Pollut, 162, 361, 2012.

22. BERTOL I., ENGEL F.L., MAFRA A.L., BERTOL O.J., RITTER S.R. Phosphorus, potassium and organic carbon concentrations in runoff water and sediments under different soil tillage systems during soybean growth. Soil Till Res, 94, 142, 2007.

23. BARBOSA F.T., BERTOL I., LUCIANO R.V., GONZALEZ A.P. Phosphorus losses in water and sediments in runoff of the water erosion in oat and vetch crops seed in contour and downhill. Soil Till Res, 106, 22, 2009.

24. LIU R.M., WANG J.W., SHI J.H., CHEN Y.X., SUN C.C., ZHANG P.P., SHEN A.Y. Runoff characteristics and nutrient loss mechanism from plain farmland under simulated rainfall conditions. Sci Total Environ, 468, 1069, 2014.

25. FILIZ Y., TURAN Y. Growth performance of Sainfoin and its effects on the runoff, soil loss and sediment 
concentration in a semi-arid region of Turkey. Catena, 133, 309, 2015.

26. VAEZI A.R., ZARRINABADI E., AUERSWALD K. Interaction of land use, slope gradient and rain sequence on runoff and soil loss from weakly aggregated semi-arid soils. Soil Till Res, 172, 22, 2017.

27. LIU D.D., SHE D.L., YU S.E., SHAO G.C., CHEN D. Rainfall intensity and slope gradient effects on sediment losses and splash from a saline-sodic soil under coastal reclamation. Catena, 128, 54, 2015.

28. ZHANG X.Q., HU M.C., GUO X.Y., YANG H., ZHANG Z.K., ZHANG K.L. Effects of topographic factors on runoff and soil loss in Southwest China. Catena, 160, 394, 2018.

29. MCDOWELL R.W., SHARPLEY A.N. Approximating phosphorus release from soils to surface runoff and subsurface drains. J. Environ. Qual, 30, 508, 2001.

30. EKHOLM P., RITA H., PITKÄNEN H., RANTANEN P. Alga-available phosphorus entering the Gulf of Finland as estimated by algal assays and chemical analysis. J. Environ. Qual, 38, 2322, 2009.
31. MCDOWELL R.W., NASH D. A review of the costeffectiveness and suitability of mitigation strategies to prevent phosphorus loss from dairy farms in New Zealand and Australia. J. Environ. Qual, 41, 680, 2012.

32. HE J., SU D.R., LV S.H., DIAO Z.Y., BU H., WO Q. Analysis of factors controlling soil phosphorus loss with surface runoff in Huihe National Nature Reserve by principal component and path analysis methods. Environ Sci Pollut Res, 25, 2320, 2018.

33. HAO Q.J., CHENG B.H., JIANG C.S. Comparison of loess and purple rill erosions measured with volume replacement method. J. Hydrol, 530, 476, 2015.

34. LIU C., DING N.F., FU Q.L., PHILIP C., BROOKES, XU J.M., LIN Y.C., LI H., LI N.Y. The influence of soil properties on the size and structure of bacterial and fungal communities along a paddy soil chronosequence. Eur J Soil Biol, 76, 9, 2016.

35. WANG W., WU X.H., YIN C.M., XIE X.L. Nutrition loss through surface runoff from slope lands and its implications for agricultural management. Agr Water Manage, 212, 226, 2019. 
